\title{
A Career Perspective on the Discipline of Neurochemistry
}

\author{
George H. DeVries
}

Published online: 25 December 2008

(C) Springer Science+Business Media, LLC 2008

I am honored to have this issue of Neurochemical Research dedicated to my career.

There have been monumental changes in the discipline of neurochemistry from the time that I began my training in neurochemistry (1969) to the present time. Rather than recounting a chronology of my career in this chapter, I prefer to relate how the perception and practice of neurochemistry has evolved over the course of my career.

I am an "accidental neurochemist" never having intended to be involved in any discipline other than biochemistry, the field in which I obtained my degree from the University of Illinois at Chicago in 1969. My graduate advisor (Dr. Stephen Binkley) supported part of my graduate training under the auspices of a new neuroscience training program directed by Dr. Klaus Unna in the Pharmacology Department. Neuroscience was a relatively new term at that time, and having received a BS in Zoology from Wheaton College (Illinois), I gladly accepted the challenge of learning more about the nervous system. I was quite sure this experience would be a temporary excursion from my clear goal of a career in biochemistry. After taking a few required neuroscience courses in the program, to my surprise, I became intrigued with the nervous system. I recognized that detailed biochemical studies of the nervous system were in their infancy. Indeed, the flagship journal which detailed such studies (Journal of

Special issue article in honor of Dr. George H. DeVries.

G. H. DeVries ( $($ )

Research Service, Hines V.A. Hospital, Hines, IL 60141, USA

e-mail: George.DeVries@VA.gov

G. H. DeVries

Department Anatomy and Cell Biology, University of Illinois Chicago, School of Medicine, Chicago, IL 60612, USA
Neurochemistry) was less than 10 years old at the time I began my graduate studies. My graduate research was quite removed from the nervous system and involved the isolation and purification of an enzyme from Clostridium perfringins ( $N$-acetyl neuraminic acid aldolase) and subsequent characterization of its mechanism of action $[1,2]$. At the time, I had no idea that this purified enzyme would be my ticket to a career in neurochemistry.

As I approached the end of my graduate studies, I decided to focus my postdoctoral studies in neurochemistry. I was particularly interested in understanding the molecular basis of learning and memory. At that time (1969), there were a number of investigators doing foundational studies in that field. I was fortunate to obtain a postdoctoral position with Sam Barondes who at the time was in the Department of Psychiatry at the Albert Einstein College of Medicine. Sam was interested in the turnover of sialic acid at the synapse and how this might relate to memory and learning. To carry out these studies, he needed large quantities of radioactively labeled sialic acid. Labeled sialic acid could not be purchased at that time, but the enzyme that I had purified could be used to combine $N$-Acetyl mannoseamine with radioactive pyruvate (which was commercially available) to generate highly labeled sialic acid. I left Chicago and the bitter cold winters to head back to the east coast where I had grown up in Northern New Jersey (Fair Lawn), a small town to which my great grandfather had migrated from the Netherlands. After 9 years in the Midwest, I was quite confident I would never be back there again (I was wrong on that score as well!). With the aldolase enzyme in hand, I began my studies with Sam in the summer of 1969. Despite the skeptics and naysayers, we were able to show that radioactive sialic acid could be used as a tracer in vivo and that this tracer was stably incorporated into glycoproteins and glycolipids [3]. Sam's lab was an exciting and 
stimulating place to be for a fledgling neurochemist, due in no small part to the other members of the lab including two MD/Ph.D. students (Marty Zatz and Howard Feit) and two postdocs (Larry Squire and Gary Dutton). Unfortunately, Sam left for California in December, and I was left to decide what to do next. Sam's departure coincided with the departure of a postdoctoral student from Bill Norton's lab, and I was able to transfer as a postdoctoral fellow from Psychiatry to Neurology (see article in this issue by Bill Norton). In 1970, I began my studies on the isolation and characterization of defined cellular constituents of the CNS.

Even though I was at the beginning of my career, I realized that the term "neurochemistry" would not accurately reflect what I aspired to do in my career. It was no longer enough to characterize the chemical constituents of the nervous system. Rather, I realized that to make real progress in understanding the nervous system, a multidisciplinary approach would be required. I would have to learn something about neuroanatomy, neurophysiology, neuropharmacology and neuropathology if I wanted to be successful in my adventures in neurochemistry. The research environment at Albert Einstein College of Medicine embraced all these disciplines and brought them to bear on understanding the nervous system. There were excellent neurochemists in the neurology department, including Bill Norton (who trained as an organic chemist at Princeton and was recruited by Saul Korey to study the chemical makeup of the CNS, particularly myelin), Bob Ledeen, (who also was also initially trained as an organic chemist, and was an expert in brain lipids, particularly gangliosides), and his close associate, Robert $\mathrm{Yu}$, (who went on to eventually become my chair at the Medical College of Virginia). These neurochemists interacted regularly with neurologists (Bob Katzman and Kuni Suzuki) and neuropathologists (Bob Terry, Mike Shelanski), as well as scientists trained to examine nervous tissue by electron microscopy (Cedric Raine). I learned that even though I was a neurochemist at heart, I would need to interact and learn from scientists in other disciplines rather than solely associating with other "neurochemists". Thus at an early stage of my career, I recognized that, although I would be a neurochemist, I could not limit my investigations to a single discipline and that my studies in neurochemistry would always seek to include a clinical application.

My two and one-half year stint at Albert Einstein (when I was a "young" neurochemist—see article by Norton in this issue) was exciting and productive. My project was to further refine a procedure to isolate "myelin-free axons", which had been initially devised by Bill Norton and Julie Turnbull (see article by Norton this issue).The "myelinfree" axon preparation was isolated and characterized from the CNS [4-6], and I collaborated in the first isolation of a neurofilament fraction from the CNS [7]. The seminal finding from these early studies was that glycolipids such as cerebroside and sulfatide were found in appreciable amounts in a non-myelin fraction enriched in axonal filaments derived from myelinated axons [5]. In addition, we noted that the fatty acid composition of the glycolipids found in myelin-free axons was distinct from that of the same glycolipids found in a myelin fraction simultaneously isolated with the myelin-free axon preparation [6]. I left Einstein with a deeper understanding of the nervous system two papers in Science, $[4,7]$ two papers in the Journal of Neurochemistry, [5, 6] and a review paper in the first volume of the new Journal of Neuroscience Research [8].

Ready to begin my independent career, I searched for a suitable place for someone trained in biochemistry and experienced in neuroscience. I quickly realized that there were no departments of neurochemistry since it was too specialized at that time to merit an independent department. I decided to accept a position in the Biochemistry Department at the Medical College of Virginia in Richmond (now called the Health Sciences Division of Virginia Commonwealth University), since it offered independence and a chance to develop my own program.

Like many neurochemists at that time, I found neurochemistry to be a lonely discipline. In 1972, biochemists were busily exploring the wonders of DNA and translational and transcriptional control as well as crystalline structure and conformational changes in proteins. My colleagues in biochemistry considered my goal of isolating defined cellular fractions from the nervous system and characterizing their biochemical composition as quite primitive. Fortunately, within a year I was able to obtain my first R01, and my career as a neurochemist was launched. I hired my first technician (Debbie Lewis) and accepted my first graduate student (Carson Cornbrooks), and my career was off and running.

My research goal was to carry out metabolic studies of the myelin-free axons. The first step was to work out the isolation of the myelin-free axonal fraction from rat CNS and show that this neuronal fraction also had glycolipids which were characteristic of myelin [9]. Subsequently, we refined the myelin-free axon preparation to allow the isolation of a fraction enriched in the axolemma termed the axolemma-enriched fraction or AEF [10]. This procedure was accomplished by isolating myelinated axons from a white matter homogenate prepared with gentle homogenization in a $0.85 \mathrm{M}$ buffered isotonic solution which would preserve the integrity of the myelin around the axons. Upon centrifugation of this homogenate, the myelin acted as a kind of "life preserver" allowing flotation of myelinated axons to the surface of the sucrose while the non-myelinated constituents formed a pellet at the bottom of the tube after centrifugation. Subsequently, the myelinated axons 
were vigorously homogenized in a hypotonic solution so that the three major constituents of the myelinated axon (myelin, axolemma and axonal filaments) were physically separated from each other. In the original AEF procedure, a three-step discontinuous gradient was used to fractionate the shocked myelinated axons into two AEF fractions at the $0.8 / 1.0 \mathrm{M}$ sucrose interface and the 1.0 and $1.2 \mathrm{M}$ sucrose interface [10-12]. A refinement of the technique involved the use of a continuous 10-40\% gradient followed by equilibrium centrifugation of the shocked myelinated axon preparation to obtain a membrane fraction in the $28-32 \%$ region of the density gradient $[13,14]$. This fraction had a biochemical profile consistent with an axolemmal origin. The AEF was initially isolated from the readily available bovine CNS white matter of the corpus callosum [10], Subsequently, AEF was isolated from the more heavily myelinated tracts of the CNS found in the brainstem and cerebellar peduncles [14]. AEF was also isolated and characterized from a number of other species including the rat, rabbit, and human [11, 12, 15]. Rather than only characterizing the lipid and enzymatic profile of the AEF, we carried out a number of collaborative studies concerning metabolic capacities of the AEF and glial cells as shown in Table 1.

A critical milestone in my career was the receipt of a Javits Neuroscience Award in 1984. This 7 year award gave me a much needed respite from grant writing and gave me the opportunity to gain focus in my career in neurochemistry. It is interesting to note that this award was not given for development in a traditional discipline but for neuroscience in general, reflecting the de-emphasis of individual disciplines in the investigation of the nervous
Table 1 Collaborative studies with DeVries laboratory

\begin{tabular}{|c|c|c|}
\hline Collaboration & Study & Reference \\
\hline Larry Eng & Protein composition of myelin-free axons & {$[16]$} \\
\hline J.-M. Matthieu & Glycoprotein metabolism in AEF & {$[17]$} \\
\hline Eluira Costantino-Cecarini & Galactosyl transferase in AEF & {$[18]$} \\
\hline C.J. Waechter & Dolichol metabolism & {$[19,20]$} \\
\hline H. Webster & Freeze fracture analysis of $\mathrm{AEF}$ & {$[15]$} \\
\hline J. Salzer/R. Bunge & Mitogenicity of AEF for Schwann cells & {$[21]$} \\
\hline J. Griffin & Isolation of AEF From peripheral nerve & {$[22]$} \\
\hline J. Kanfer & Phospholipase D in AEF & {$[23]$} \\
\hline T.J. Sprinkle & Localization of CNP in Schwann cells & {$[24]$} \\
\hline F.J. Seil & Biological activity of antisera to AEF & {$[25,26]$} \\
\hline R.K. Yu & Glycolipids in AEF & {$[27]$} \\
\hline G.M. McKhann/G. Tenekoon & Creation of rat Schwann cell line & {$[28]$} \\
\hline N.L. Banik & Calpain in myelinating glia & [29-32] \\
\hline E. Stubbs & Peripheral neuropathy & {$[33]$} \\
\hline T.F. Huff & Stem cell factor in Schwann cells & [34] \\
\hline M. Kalimi/W. Regelson & Glucocorticoids and Schwann cells & {$[35]$} \\
\hline M.J. Monteiro & Neurofilament phosphorylation and myelination & {$[36]$} \\
\hline A. Welcher, D. Wen & Neuregulins and oligodendrocytes & {$[37,38]$} \\
\hline D.A. Green & Glucose transporters in Schwann cells & [39] \\
\hline J.P. Antel & Neuregulins in human oligodendrocytes & {$[40]$} \\
\hline K.J Jones & Neurotrophins in olfactory ensheathing cells & {$[41]$} \\
\hline P. LoPresti & Regulation of oligodendrocyte tau by neuregulin & {$[42]$} \\
\hline G.C. LeBreton & Thromboxane receptors in schwann cells & [43] \\
\hline S.E. Crawford & Schwann cells and pigment epithelium-derived factor & {$[44,45]$} \\
\hline R.H. Quarles & Schwann cell lines & [46] \\
\hline R.D. Fields & Transcriptional profiling of Schwann cells & {$[47]$} \\
\hline D.W. Clapp & GAP domain in Schwann cells lines & {$[48]$} \\
\hline D. Muir & Schwann cell line tumors in vivo & [49] \\
\hline M. Kies/G. Diebler & Mitogenicity of myelin basic protein & {$[50-52]$} \\
\hline J. Dupree & EM Studies of demyelination & Current \\
\hline D. Feinstein & EAE and inflammation & Current \\
\hline G. Kartje & Plasticity in the CNS & Current \\
\hline
\end{tabular}


system and the emergence of an integrated approach to understanding the nervous system.

Up to this point, although my research still fit in the rubric of biological chemistry and neurochemistry, I was considered something of a maverick in my Biochemistry Department. I realized that I would not be successful if I limited my research to neurochemistry and did not incorporate other disciplines into my approach, particularly with respect to the impact of these studies on a disease process. I was not unique in this awareness since at this time the neurochemical journals were beginning to include morphology and neurophysiology in their articles.

I broadened my research to include disciplines other than neurochemistry. I began to collaborate and interact with a local neurologist (Vince Calabrese), who made me aware of how AEF could play an important role in demyelinating disease [53]. We found that AEF is highly antigenic [54]. Exposure of this membrane after a demyelinating insult may lead to the production of autoantibodies which can damage neurons and prevent remyelination [53]. In collaboration with an eminent neuropathologist (Harry Webster), we carried out freeze fracture studies of AEF to show that the majority of the membrane vesicles have a right side out orientation and a freeze-fracture morphology which was consistent with their axolemmal origin [15]. I was fortunate to serve with prominent tissue culturist (Dick Bunge) on a NICHD National Institute of Child Health and Human Development Study Section. As a result of my interactions with Dick Bunge, we began an excellent collaboration involving tissue culture and AEF. Working closely with Jim Salzer, who was a MD/Ph.D. student in the Bunge laboratory at that time, we found that AEF from either the CNS or the PNS could act as a potent mitogen for cultured Schwann cells [21]. This seminal observation lead me away from "grinding and finding" to an emphasis on in vitro metabolic responses to the isolated AEF. Cell culture was set up in the laboratory by my first postdoc (Lee Minier), a research technique that has continued in my laboratory to this day.

Our laboratory combined neurochemistry with this new emphasis on in vitro studies. Jun Yoshino and John Bigbee [55-57] made the serendipitous observation that myelin itself was mitogenic for Schwann cells. This mitogenicity only became evident when a Richmond snowstorm prolonged the mitogenic assay to $48 \mathrm{~h}$. Further studies carried out by Shun-Fen Tzeng and Roopa Baichwal revealed that the myelin mitogen was produced by macrophage processing [58] and resides in myelin basic protein [59, 60]. Two sequences of myelin basic protein were identified as mitogenic [50] and the receptors for these mitogens were identified [51]. Tzeng et al. [52] noted that MBP stimulated apoptosis in cultured oligodendrocytes. These studies would not have been possible without the collaboration of Marian Kies, (a prominent MBP neurochemist intimately familiar with MBP) and her technician, Gladys Deibler. AEF also stimulated Schwann cell differentiation as evidenced by increased expression of the mRNA of the major glycoprotein of peripheral myelin [61]. The axonal molecules responsible for these metabolic activities have been partially characterized [62], but a complete understanding of the axonal molecules which orchestrate the myelination process in the CNS is still not known.

My neurochemical interests were stimulated by collaborators and creative students in our laboratory. I was fortunate to meet Andy Welcher at the first Gordon Conference on Myelin (1992) who asked me to study the effects of a newly discovered molecule called neu differentiation factor (now known as neuregulin) on myelinating glial cells $[37,38]$ A series of studies carried out by a postdoctoral fellow in my laboratory, Tim Raabe, documented the effects and localization of neuregulins in glial cells [38, 39, 63-66]. Another postdoctoral fellow in my laboratory Olga Calderon, (in collaboration with Bruno Maggio) carried out creative neurochemical studies of the AEF. They were able to spread the AEF as a monolayer, transfer it to a coverslip, and demonstrate that the packing density of the monolayer influenced the mitogenic signaling capacity of the monolayer to Schwann cells cultured on the monolayer [67, 68].

At the time that these in vitro studies were in progress, I began to think of myself more as a neuroscientist than strictly as a neurochemist, although the lines between them were still somewhat blurred. Nowhere is the overlap and lack of clarity between neurochemistry and neuroscience more evident than in the history of the American Society for Neurochemistry (ASN). This society was founded in 1970 , the same year as the founding of the Society for Neuroscience (SFN). Currently, there are over 38,000 members in the SFN while the ASN has a membership of approximately 1,200 . This disparity appears to be due in large part to the more restrictive term, "neurochemist", as opposed to the more inclusive moniker of "neuroscientist" which can fit anyone who was researching any aspect of the nervous system. Researchers flocked to the SFN in unprecedented numbers to create one of the largest professional societies in the world, while the ASN grew at a much more modest rate. The officers in ASN began to recognize this issue and the nature and scope of the ASN annual meetings began to change to more resemble a "mini SFN meeting". I have been fortunate to attend all but one of the meetings of the ASN and have observed that prominent keynote speakers would often apologize at the beginning of their talks for not being a "card carrying neurochemist". No such apology was really necessary since most of those in attendance at that point would call 
themselves primarily neuroscientists with a focus on neurochemistry.

It seems that neurochemistry has had, and still has, an identity problem. Neurochemistry may be defined as the branch of neuroscience devoted to the study of neurochemicals which are organic molecules which comprise nervous tissue or which participate in neural activity. This definition is quite limiting so that few scientists would be willing to identify themselves primarily as a neurochemist. The nature of research in the nervous system has dramatically changed from the time of the first neurochemist, Thudichum [69], who only had elemental analysis at his disposal as a means of investigating the molecules of the nervous system. This is in stark contrast to the tools at our disposal today, including gene chips, transgenic technology to knock out genes and the loxP technique to selectively delete genes at a given time, electrophysiology, tissue culture, gene amplification and gene silencing as well as a very sophisticated collection of highly precise optical devices. This elegant instrumentation allows for investigations that are more functional and beyond the scope of neurochemistry alone.

At the beginning of my career, basic science was considered the "holy grail" of research with little or no attempt to relate the research to a specific disease. This focus on basic research has radically changed over the years so that now few neuroscience laboratories focus solely on pure basic research, but rather emphasize a "bench to bedside" goal. The initial focus of our laboratory was the isolation and biochemical characterization of cellular constituents from the CNS which were relevant to CNS disorders such as multiple sclerosis. However, I also found myself interested in diseases of the PNS, since many of my initial studies concerning the metabolic effects of AEF were focused on the myelinating cell of the PNS, the Schwann cell. Our laboratory developed methods to isolate a fraction enriched in axolemma of peripheral nerves [22,70]. At this point in my career, a genetics graduate student (Karen Klein) joined my lab with a passion to study Schwann cells in the context of disease, particularly neurofibromatosis (a disease in which Schwann cells proliferate abnormally and form tumors) (see [71] for a recent review). As a result, we began a 15 year investigation by my lab into the signal transduction abnormalities which resulted in tumor formation by these aberrant Schwann cells [34, 47-49, 72-77]. These studies could easily be classified as strictly neurochemical, but the pendulum was swinging toward more holistic and applied research with less emphasis on molecular and descriptive studies.

I was fortunate in my career to always have a close association with neurologists (in Virginia, Vince Calabrese, and in Illinois, Wendy Kartje) who were familiar with the clinical realities of the emerging emphasis on bench to bedside research. My interactions with these clinician/scientists have steered my research toward more functional studies of neurological diseases. I began to explore the possible relationships of neuronal antibodies to cryptic neuronal antigens $[25,26,53,78]$ before the importance of neurons in demyelinating disease was fully recognized or appreciated. More recently, my laboratory has been carrying out studies concerning the role of plasticity in promoting recovery from demyelinating disease [79], as well as studies of the effects of a new drug (didox) on the progression and reversal of experimental allergic encephalomyelitis (EAE) [80]. These projects require in vivo studies which, I have learned, have a different time-scale and administrative difficulty when compared with in vitro studies. Most in vivo experiments take 6-8 weeks before the results are known and if changes are indicated. A similar time period elapses before you learn if the changes were beneficial. Since these studies involve animals, every change in the experimental protocol requires either a modification of an existing animal protocol or submission of a new animal use protocol for review, another time-consuming process. Carrying out in vivo studies moves one farther away from neurochemistry in that the focus goes beyond molecules and evaluates more global aspects, such as behavior. Nevertheless, components of the studies could still be considered neurochemistry such as analyzing molecules derived from tissues in a given study. For example, our neurochemical studies deal with the influence of didox on the levels of inflammatory mediators produced by splenocytes in EAE. Our laboratory is also currently evaluating, in vivo, the ability of human neural stem cells to promote plasticity after demyelination and the ability of neural stem cell derived oligodendrocytes to promote myelination in CNS tissue slices. Given the nature of these studies, can I still be considered a neurochemist?

If the definition of neurochemistry is "the branch of neuroscience devoted to the study of neurochemicals" and the underlying basis of holistic studies is molecular in nature, I would answer that question with a qualified "yes". I am a neurochemist in that I still study and characterize molecules as part of the investigation of the nervous system. However, my research focus has moved beyond characterizing molecules and surmising function to an emphasis on recovery from demyelinating disease using animal models. Yet, my professional identity is linked to neurochemistry by virtue of my long standing association with the ASN, as a former President (2003-2005) and a continuing active member. I was also trained in the neurochemical tradition which encourages careful characterization of molecules in neural tissue as a valuable goal of research. Perhaps the best indicator of the degree to which my laboratory could be considered a neurochemical laboratory is to consider the career paths of the many talented 
postdocs and graduate students who have passed through the laboratory. Several of these students distinguished themselves by their productivity and accomplishments during their tenure in my laboratory. Specifically, the following students published at least one paper per year while in graduate school (numbers of papers in parentheses) Pat Mason (6), Shun-Fen Tzeng (4), Roopa Baichwal (6), Naser Muja (5), and Stacey Thomas (6). While numbers do not tell the whole story, I can truthfully say it was a pleasure and a privilege to have each of these students as members of my laboratory. Several postdoctoral fellows also distinguished themselves by there productivity, including: Jun Yoshino (13), John Bigbee (13), Tim Neuberger (who was my first graduate student's graduate student) (18), Tim Raabe (8), and Gail Deadwyler (7). Two of these remarkable postdoctoral fellows are the co-editors of this volume! I can honestly say it was a joy to have each of these talented individuals in my laboratory. They contributed not only to the productivity of the laboratory but to the education and mentoring of the graduate students who were in the lab at that time. In addition, I was fortunate to have several non-degree seeking medical students in my laboratory (Jeff Stanley and Jim Meador-Woodruff) as well as a dental student (Alex McDonald) who had a Ph.D. and wanted to stay active in bench research. Each of these students brought a unique perspective to the laboratory and contributed substantially to the growth and productivity of the laboratory.

I doubt that any of these students or postdocs would classify themselves as "neurochemists" or would even necessarily identify my laboratory as a "neurochemistry laboratory". More likely, they would classify my laboratory as a neuroscience laboratory with an interest in myelinating glial cells and demyelinating disease.

One may be tempted at this point to ask the broader question, "Does neurochemistry still exist?" I would answer with a limited-"yes" in that every study of the nervous system ultimately comes down to molecules which need to be identified, classified and quantified. However, few current investigators with a research interest in the nervous system would classify themselves strictly as neurochemists. This is in contrast to the founding fathers of the ASN who had no hesitation in asserting their profession as "neurochemistry."

What has changed? One factor is the emphasis on the more holistic studies of the nervous system which are possible today due to improved technology. No longer are scientists limited to the tedious extraction procedures first described by Thudichum [69] and refined by Folch-Pi, especially as they pertained to lipid extraction [81]. Sophisticated instrumentation is now available for in depth, neurophysiological, neuroanatomical and neuropathological studies. From the perspective of a neurochemist, these studies still have a molecular basis, but the studies as a whole would not be considered solely neurochemical. Funding priorities have been another change in the scope and focus of investigations in the nervous system. Most funding agencies, with the possible exception of the National Science Foundation, base funding priorities on neurodegenerative diseases not on disciplines. Rarely would one if ever see the term neurochemistry in the title of a funding agency. Consider the agencies which have funded my own research through the years (Table 2). Nowhere in the title of the funded grants does the term "neurochemistry" appear.

Another reality for scientists today is the need to keep the laboratory funded by identifying identify and adapting projects to appeal to multiple agencies. I was fortunate in having 23 years of continuous funding from the NINDS in the grant entitled "Molecular Basis of Axolemmal Glial Interactions" (NS10821). This grant was complemented by another 16 year funded NINDS grant "Axolemmal and Myelin-induced Schwann cell proliferation" (NS15408) which focused on studies of PNS neuronal-glial interactions. Along with these two grants, I had substantial support from the National Multiple Sclerosis Society and a number of disease-related grants as the opportunity arose to apply and get support from these agencies. As time progressed, the titles of the grants became more and more concerned with functional recovery from a neurodegenerative disease and less concerned with characterization of molecules of the nervous system (i.e., "neurochemistry"). However, like many others with their roots in the neurochemical tradition, all of my proposals had neurochemistry as an integral component.

The neurochemical studies that have been carried out could not have been done without the help of competent technicians and administrative assistants (in particular Cathleen Finnerty and Jean Egerman) who have worked in my laboratory over the years. Administrative assistants provide a substantial benefit to researchers since they free the researcher from the ever increasing amount of paper work required to run a laboratory. As a result, the researcher has time to actually think about his research and interact with students and technicians. The educational backgrounds of my technicians also reflect the changing nature of neurochemistry. My initial technicians had strong backgrounds in analytical chemistry and a few of them had been clinical chemistry technicians. At that time, I was situated in a Department of Biochemistry in the School of Medicine. In this department, molecules were of paramount importance. Currently, my academic affiliation is with a Department of Anatomy and Cell Biology with less emphasis on molecules and more emphasis on morphology. At this time, my technicians tend to come from more general backgrounds such as biology; with my most recent 
Table 2 Agencies which funded research in DeVries laboratory

\begin{tabular}{|c|c|c|}
\hline & Title & Dates \\
\hline \multicolumn{3}{|l|}{ Government agencies } \\
\hline NIH-NINDS (NS 10821) & Molecular basis of axolemma-glial interaction & 1973-1996 \\
\hline NIH-NINDS (NS 15408) & Axolemmal and myelin-induced Schwann cell proliferation & 1979-1994 \\
\hline Veterans Administration & Glial cell response to myelin-derived peptides & 1997-2001 \\
\hline Veterans Administration & Immune-mediated axonal damage in multiple sclerosis & 2005-2009 \\
\hline $\begin{array}{l}\text { Department of Defense Congressionally Directed Medical } \\
\text { Research Program }\end{array}$ & Molecular mechanisms of Schwann cell proliferation in NF1 & 1998-2001 \\
\hline National Science Foundation & Isolation of PNS axolemma & 1974-1976 \\
\hline \multicolumn{3}{|l|}{ Private agencies } \\
\hline National Multiple Sclerosis Society & $\begin{array}{l}\text { Eight separate grants dealing with axon-oligodendrocyte } \\
\text { interactions in multiple sclerosis }\end{array}$ & $1977-2000$ \\
\hline $\begin{array}{l}\text { National Multiple Sclerosis Society (Senior Postdoctoral } \\
\text { Fellowship with Dr. Larry Eng) }\end{array}$ & Molecular mechanisms of myelination & 1991-1992 \\
\hline American Heart Association & Neuregulins, nogo and stroke recovery & 2002-2004 \\
\hline Christopher Reeve Foundation & Neuregulin metabolism in spinal cord injury & $2002-2003$ \\
\hline Amgen Inc. & Effects of NDF on glial cells & 2003-2004 \\
\hline Neuro Tech & Role of NDF in glial cell function & 1984-1985 \\
\hline American Diabetes Foundation & The role and regulation of Schwann cell insulin receptors & $1991-1993$ \\
\hline Mass. Bay NF Inc. & Role of oncogenes in the etiology of neurofibromatosis & 1994-1997 \\
\hline Molecules For Health & Didox therapy for demyelinating disease & $2007-2010$ \\
\hline Illinois Regenerative Medicine Institute & Stem cell therapy for recovery from demyelinating disease & 2006-2009 \\
\hline Illinois Regenerative Medicine Institute & $\begin{array}{l}\text { Engineering stem-cell derived oligodendrocytes for } \\
\text { demyelinating disease }\end{array}$ & $2008-2010$ \\
\hline
\end{tabular}

technician (Christian Campbell) being a communication major! This new diversity of backgrounds also reflects the changing nature of my research, with less emphasis on only neurochemistry and more emphasis on the interdisciplinary aspects of neuroscience.

My neurochemical studies were also enhanced by three sabbatical leaves that I had while a faculty member in the
Department of Biochemistry and Molecular Biophysics at the Medical College of Virginia. (A listing of my positions and appointments during my career is shown in Table 3.) These sabbaticals included 9 months collaboration with Dr. Jean-Marie Matthieu at the University of Lausanne in Switzerland and was supported by the Roche Pharmaceutical under the auspices of their "Foundation for the

Table 3 Chronology of DeVries career

\begin{tabular}{|c|c|c|c|}
\hline Institution & Dept/Specialization & Position/Degree & Years \\
\hline Wheaton College Wheaton, Illinois & Zoology & BS. Cum laude & 1960-1964 \\
\hline University of Illinois School of Medicine, Chicago, IL & Biochemistry & Ph.D. & 1964-1969 \\
\hline Albert Einstein College of Medicine, Bronx, New York & Phychiatry & Post Doctoral (S. Barondes) & $1969-1970$ \\
\hline Albert Einstein College of Medicine, Bronx, New York & Neurology & Post Doctora (W. Norton)1 & 1970-1972 \\
\hline Medical College of Virginia, Biochemistry & Biochemistry & Assistant Professor & $1972-1975$ \\
\hline Medical College of Virginia. Biochemistry & $\begin{array}{l}\text { Biochemistry and Molecular } \\
\text { Biophysics }\end{array}$ & Associate Professor & 1975-1983 \\
\hline Medical College of Virginia, Biochemistry & $\begin{array}{l}\text { Biochemistry and Molecular } \\
\text { Biophysics }\end{array}$ & Professor & 1983-1995 \\
\hline Loyola University Stritch School of Medicine, Chicago, IL & Cellular Biology and Neuroanatomy & Professor & 1995-2004 \\
\hline $\begin{array}{l}\text { Professor, University of Illinois, School of Medicine, } \\
\text { Chicago, IL }\end{array}$ & Anatomy and Cell Biology & Professor & 2004 \\
\hline Hines VA Hospital; Hines, IL & Research & Research Health Scientist & 1995-2000 \\
\hline Hines VA Hospital; Hines, IL & Research & $\begin{array}{l}\text { Career Research Health } \\
\text { Scientist }\end{array}$ & 2000 \\
\hline
\end{tabular}


Collaboration and Exchange with Switzerland." During this time, we refined the axolemma-enriched preparation and carried out metabolic labeling studies of this fraction [11, 17]. In 1980, I received a Fogarty Foundation Grant to work in the laboratories of Dr. Michel Lazdunski at University of Nice, France (although my colleagues doubted the sincerity of my intentions given the location on the Cote'd'azure!). However, I did successfully carry out binding studies of the AEF with radiolabeled neurotoxins which revealed the presence of sodium channels in the fraction as well as revealing the outside-out orientation of the AEF vesicles [82]. Finally, in 1991, I was awarded a National Multiple Sclerosis Society Senior Fellowship which enabled me to spend a year in the laboratory of Dr. Larry Eng at the Palo Alto VA Hospital to learn molecular biological techniques. These sabbatical experiences honed my skills in neurochemistry and influenced my subsequent studies.

In summary, during the span of my career, I have seen profound changes in the discipline of neurochemistry. After the anatomical landmarks of the nervous system had been established by the early pioneers in the study of the nervous system, understanding the molecular nature of the nervous tissue became the next priority for research. It was during this time span from Thudichum through the first half of the twentieth century that "neurochemistry" as a discipline reigned supreme Once the fundamental molecules which comprised the nervous system were identified and described with some certainty, investigators began to broaden their investigations under the rubric of the emerging discipline of neuroscience. However, from the perspective of a neurochemist, molecules form the foundation from which all studies of the nervous system emerge.

There are several reasons why the discipline of neurochemistry will continue. First there are strong societies which are founded within the discipline of neurochemistry. These societies will continue to hold meetings and promote the discipline of neurochemistry (see listing in Table 4). These societies will also be a constant reminder to emerging scientists that there is a branch of neuroscience which is

Table 4 Current neurochemical societies in the world

Year established

\begin{tabular}{ll}
\hline International societies & \\
International Society for Neurochemistry & 1967 \\
American Society for Neurochemistry & 1970 \\
European Society for Neurochemistry & 1976 \\
Asian Pacific Society for Neurochemistry & 1991 \\
National societies & 1962 \\
Japanese Society for Neurochemistry & 1986 \\
Argentine Society for Neurochemistry & \\
Chinese Society for Neurochemistry & \\
\hline
\end{tabular}

concentrated on the study of molecules of the nervous system. It is interesting to note, however, that these societies embrace the broader aspects of neuroscience. By looking at the scientific programs of their annual meetings, one would be hard pressed to know what distinguishes the program of the neurochemical meetings from that of the annual meeting of the Society for Neuroscience. Indeed, the slogan of the ASN (introduced by Scott Brady when he was President) is "The Latest in Molecular and Cellular Neurobiology" This labeling signals that ASN is broader than "neurochemistry." A second reason for the retention of neurochemistry as a discipline is the existence of neurochemical journals, such as this one. These neurochemistry journals will continue to enhance and bring to the awareness of scientists the discipline of neurochemistry. It is interesting to note that the neurochemical journals now include studies and data that are not strictly speaking, "neurochemical". Thus both the neurochemical societies and the neurochemical journals tacitly acknowledge that the discipline of neurochemistry while essential, is only part of the quest for understanding the nervous system. A former chair of mine liked to state that biochemistry (the discipline in which I was first trained) "is the fountainhead from which all other streams of knowledge flow". The same could be said of neurochemistry, which in a sense is the application of biochemistry to the study of the nervous system. Although other disciplines have joined neurochemistry in seeking to understand the workings of the nervous system, neurochemistry will always remain foundational to these approaches.

Acknowledgments I regret that I was not able to fully acknowledge all the students and collaborators who have participated in and contributed to my laboratory over the years. I am profoundly grateful for the encouragement and support of my wife Helen, who has supported me through the joys and challenges of my career. I am also grateful to my children Jori Elizabeth and James Thomson who understood when their dad was absent due to grant deadlines and scientific meetings. I thank my many collaborators who not only enriched my scientific career but who have become lifelong friends. Thanks also to the many agencies who judged my ideas to be worthy of support throughout my career. The students and postdocs who have been part of my laboratory are my greatest source of career satisfaction and accomplishment, and I heartily thank each and every one of them for what they have contributed to my laboratory and to me as a person. I am also thankful for my faith, handed down to me by many generations of my family. This faith has sustained me and carried me through the most challenging aspects of my career in addition to giving me a proper perspective as to what really matters. Finally I am most appreciative of the time and effort expended by John Bigbee and Jun Yoshino in editing this special issue.

\section{References}

1. DeVries GH, Binkley SB (1972) N-Acetylneuraminic acid aldolase of Clostridium perfringens: purification, properties and mechanism of action. Arch Biochem Biophys 151:234-242. doi: 10.1016/0003-9861(72)90493-6 
2. DeVries GH, Binkley SB (1972) 3-Hydroxy- $N$-acetylneuraminic acid: synthesis and inhibitory properties. Arch Biochem Biophys 151:243-250. doi:10.1016/0003-9861(72)90494-8

3. DeVries GH, Barondes SH (1971) Incorporation of $\left[{ }^{14} \mathrm{C}\right] N$-acetyl neuraminic acid into brain glycoproteins and gangliosides in vivo. J Neurochem 18:101-105. doi:10.1111/j.1471-4159. 1971.tb00171.x

4. DeVries GH, Norton WT, Raine CS (1972) Axons: isolation from mammalian central nervous system. Science 175:1370-1372. doi: 10.1126/science.175.4028.1370

5. DeVries GH, Norton WT (1974) The lipid composition of axons from bovine brain. J Neurochem 22:259-264. doi:10.1111/ j.1471-4159.1974.tb11588.x

6. DeVries GH, Norton WT (1974) The fatty acid composition of sphingolipids from bovine CNS axons and myelin. J Neurochem 22:251-257. doi:10.1111/j.1471-4159.1974.tb11587.x

7. Shelanski ML, Albert S, DeVries GH, Norton WT (1971) Isolation of filaments from brain. Science 174:1242-1245. doi: 10.1126/science.174.4015.1242

8. Norton WT, Abe T, Poduslo SE, DeVries GH (1975) The lipid composition of isolated brain cells and axons. J Neurosci Res 1:57-75. doi:10.1002/jnr.490010106

9. DeVries GH, Hadfield MG, Cornbrooks C (1976) The isolation and lipid composition of myelin-free axons from rat CNS. J Neurochem 26:725-731. doi:10.1111/j.1471-4159.1976.tb04444.x

10. DeVries GH (1976) Isolation of axolemma-enriched fractions from bovine central nervous system. Neurosci Lett 3:117-122. doi:10.1016/0304-3940(76)90079-3

11. DeVries GH, Matthieu J-M, Beny M, Chicheportiche R, Lazdunski M, Dolivo M (1978) Isolation and partial characterization of rat CNS axolemma-enriched fractions. Brain Res 147:339352. doi:10.1016/0006-8993(78)90844-2

12. Zetusky WJ, Calabrese VP, Zetusky AL, Anderson MG, Cullen M, DeVries GH (1979) Isolation and partial characterization of human CNS axolemma-enriched fractions. J Neurochem 32:1103-1109. doi:10.1111/j.1471-4159.1979.tb04601.x

13. DeVries GH, Anderson MG, Johnson D (1983) Fractionation of isolated rat CNS myelinated axons by sucrose density gradient centrifugation in a zonal rotor. J Neurochem 40:1709-1717. doi: 10.1111/j.1471-4159.1983.tb08146.x

14. Detsky PZ, Bigbee JW, DeVries GH (1988) Isolation and characterization of axolemma-enriched fractions from discrete areas of bovine CNS. Neurochem Res 13:449-454. doi:10.1007/ BF01268880

15. Cullen MJ, DeVries GH, Webster H (1981) Freeze-fracture characterization of isolated myelin and axolemma membrane fractions. Brain Res 22:311-322. doi:10.1016/0006-8993(81)90996-3

16. DeVries GH, Eng LF, Lewis DL, Hadfield MG (1976) The protein composition of bovine myelin-free axons. Biochim Biophys Acta 439:133-145

17. Matthieu J-M, Webster H, DeVries GH, Corthay S, Koellreutter B (1978) Glial versus neuronal origin of myelin proteins and glycoproteins studied by combined intraocular and intracranial labelling. J Neurochem 31:93-102. doi:10.1111/j.1471-4159. 1978.tb12437.x

18. Costantino-Ceccarini E, Cestelli A, DeVries GH (1979) Characterization and developmental changes of UDP-galactose-ceramide galactosyl transferase in a rat CNS axolemma-enriched fraction. Differences and similarities of the enzyme associated with the microsomal and myelin fractions. J Neurochem 32:1175-1182. doi: 10.1111/j.1471-4159.1979.tb11044.x

19. Harford JB, Waechter CJ, Saul R, DeVries GH (1979) Evidence for the biosynthesis of mannosylphosphoryldolichol and $\mathrm{N}$-acetylglucosaminylpyro-phosphoryldolichol by an axolemma-enriched membrane preparation from bovine white matter. J Neurochem 32:91-98. doi:10.1111/j.1471-4159.1979.tb04514.x
20. Scher MG, DeVries GH, Waechter CJ (1984) Subcellular sites of enzymes catalyzing the phosphorylation-dephosphorylation of dolichol in the central nervous system. Arch Biochem Biophys 231:293-302. doi:10.1016/0003-9861(84)90391-6

21. DeVries GH, Salzer JL, Bunge RP (1982) Axolemma-enriched fractions isolated from PNS and CNS are mitogenic for cultured Schwann cells. Dev Brain Res 3:295-299. doi:10.1016/01653806(82)90028-1

22. Yoshino JE, Griffin JW, DeVries GH (1983) Identification of an axolemma-enriched fraction from peripheral nerve. J Neurochem 41:1126-1130. doi:10.1111/j.1471-4159.1983.tb09061.x

23. DeVries GH, Chalifour RJ, Kanfer JN (1983) The presence of phospholipase D in rat central nervous system axolemma. J Neurochem 40:1189-1191. doi:10.1111/j.1471-4159.1983.tb08114.x

24. Sprinkle TJ, McMorris FA, Yoshino J, DeVries GH (1985) Differential expression of $2^{\prime}: 3^{\prime}$-cyclic nucleotide $3^{\prime}$-phosphodiesterase in cultured central, peripheral, and extraneural cells. Neurochem Res 10:919-931. doi:10.1007/BF00964629

25. Bourdette DN, Seil FJ, Bigbee JW, DeVries GH, Garwood MM, Agrawal HC (1986) Antisera to an axolemma-enriched fraction inhibit neurite outgrowth and destroy axons in vitro. Brain Res 366:333-337. doi:10.1016/0006-8993(86)91313-2

26. Bourdette DN, Seil FJ, Meshul CK, Bigbee JW, DeVries GH, Agrawal HC (1988) Antisera to an axolemma-enriched fraction have antiaxon and antimyelin effects in vitro. Adv Neuroimmunol 540:423-426

27. Kohriyama T, Kusunoki S, Ariga T, Yoshino JE, DeVries GH, Latov N, Yu RK (1987) Subcellular localization of sulfated glucuronic acid-containing glycolipids reacting with anti-myelinassociated glycoprotein antibody. J Neurochem 48:1516-1522. doi:10.1111/j.1471-4159.1987.tb05694.x

28. Tennekoon GI, Yoshino J, Peden KWC, Bigbee J, Rutkowski JL, Kishimoto Y, DeVries GH, McKhann GM (1987) Transfection of neonatal rat Schwann cells with SV-40 large $\mathrm{T}$ antigen gene under control of the metallothionein promoter. J Cell Biol 105:2315-2325. doi:10.1083/jcb.105.5.2315

29. Banik NL, DeVries GH, Neuberger T, Russell T, Chakrabarti AK, Hogan EL (1991) Calcium-activated neutral proteinase (CANP; Calpain) activity in Schwann cells: immunofluorescence localization and compartmentation of $u$ - and $m$-CANP. J Neurosci Res 29:346-354. doi:10.1002/jnr.490290310

30. Neuberger T, Chakrabarti AK, Russell T, DeVries GH, Hogan EL, Banik NL (1997) Immunolocalization of cytoplasmic and myelin mCalpain in transfected Schwann cells: I. Effect of treatment with growth factors. J Neurosci Res 47:521-530. doi:10.1002/(SICI)1097-4547(19970301)47:5<521::AID-JNR7> 3.0.CO;2-J

31. Chakrabarti AK, Neuberger T, Russell T, Banik NL, DeVries GH (1997) Immunolocalization of cytoplasmic and myelin mCALPAIN in transfected Schwann cells: II. Effect of withdrawal of growth factors. J Neurosci Res 47:609-616. doi:10.1002/(SICI) 1097-4547(19970315)47:6<609::AID-JNR6>3.0.CO;2-H

32. Ray SK, Neuberger TJ, Deadwyler G, Wilford G, DeVries GH, Banik NL (2002) Calpain and calpastatin expression in primary oligodendrocyte culture: preferential localization of membrane calpain in cell processes. J Neurosci Res 70:561-569. doi: 10.1002/jnr.10414

33. Lawlor MW, Richards MP, DeVries GH, Fisher MA, Stubbs EB (2002) Antibodies to L-periaxin in sera of patients with peripheral neuropathy produce experimental sensory nerve conduction deficits. J Neurochem 83:592-600

34. Ryan JJ, Klein KA, Neuberger TJ, Leftwich JA, Westin EH, Kauma S, Fletcher JA, DeVries GH, Huff TF (1994) Role for the stem cell factor/Kit complex in Schwann cell neoplasia and mast cell proliferation associated with neurofibromatosis. J Neurosci Res 37:415-432. doi:10.1002/jnr.490370314 
35. Neuberger TJ, Kalimi O, Regelson W, Kalimi M, DeVries GH (1994) Glucocorticoids enhance the potency of Schwann cell mitogens. J Neurosci Res 38:300-313. doi:10.1002/jnr.490380 308

36. Starr R, Attema BL, DeVries GH, Monteiro MJ (1996) Neurofilament phosphorylation is modified by myelination. J Neurosci Res 44:328-337. doi:10.1002/(SICI)1097-4547(19960515)44:4< 328::AID-JNR3 > 3.0.CO;2-E

37. Raabe TD, Clive DR, Wen D, DeVries GH (1997) Neonatal oligodendrocytes contain and secrete neuregulins in vitro. J Neurochem 69:1859-1863

38. Raabe TD, Suy S, Welcher A, DeVries GH (1997) Effect of neu differentiation factor isoforms on neonatal oligodendrocyte function. J Neurosci Res 50:755-768. doi:10.1002/(SICI)10974547(19971201)50:5<755::AID-JNR12>3.0.CO;2-0

39. Magnani P, Thomas TP, Tennekoon G, DeVries GH, Greene DA, Brosius FCIII (1998) Regulation of glucose transport in cultured Schwann cells. J Peripher Nerv Syst 3(1):28-36

40. Deadwyler GD, Pouly S, Antel JP, DeVries GH (2000) Neuregulins and ErbB receptor expression in adult human oligodendrocytes. Glia 32:304-312. doi:10.1002/1098-1136(200012)32:3<304:: AID-GLIA90 > 3.0.CO;2-Z

41. Boruch AV, Conners JJ, Pipitone M, Deadwyler G, Storer PD, DeVries GH, Jones KJ (2001) Neurotrophic and migratory properties of an olfactory ensheathing cells line. Glia 33:225-229. doi:10.1002/1098-1136(200103)33:3<225::AID-GLIA1021>3.0. $\mathrm{CO} ; 2-\mathrm{Y}$

42. LoPresti P, Muma NA, DeVries GH (2000) Neu differentiation factor regulates tau protein and mRNA in cultured neonatal oligodendrocytes. Glia 35:147-155. doi:10.1002/glia.1079

43. Muja N, Blackman SC, LeBreton GC, DeVries GH (2001) Identification and functional characterization of thromboxane A2 receptors in Schwann cells. J Neurochem 78(3):446-456. doi: 10.1046/j.1471-4159.2001.00378.x

44. Crawford SE, Stellmach V, Ranalli M, Huang X, Huang L, Volpert O, DeVries GH, Abramson LP, Bouck N (2001) Pigment epithelium-derived factor (PEDF) in Neuroblastoma: a multifunctional mediator of Schwann cell anti-tumor activity. J Cell Sci 114(Pt24):4421-4428

45. Chlenski A, Liu S, Crawford SE, Volpert OV, DeVries GH, Evangensta A, Yang Q, Saiwen HR, Bray J, Cohn SL (2002) SPARC is a key inhibitor controlling Neuroblastoma tumor angiogenesis. Cancer Res 62(24):7357-7363

46. Hai M, Muja N, DeVries GH, Quarles RH, Patel PI (2002) Comparative analysis of Schwann cell lines as model systems for myelin gene transcription studies. J Neurosci Res 69(4):497-508

47. Lee PR, Cohen JE, Tendi EA, Farrer R, DeVries GH, Becker KG, Fields RD (2004) Transcriptional profiling in an MPNST-derived cell line and normal human Schwann cells. Neuron Glia Biol 1(2):135-147. doi:10.1017/S1740925X04000274

48. Thomas SL, Deadwyler GD, Tang J, Stubbs EB Jr, Muir D, Hiatt KK, Clapp DW, DeVries GH (2006) Reconstitution of the NF1 GAP-related domain in NF1-deficient human Schwann cells. Biochem Biophys Res Commun 348:971-980. doi:10.1016/ j.bbrc.2006.07.159

49. Perrin GQ, Fishbein L, Thomson SA, Thomas S, Stephens K, Garbern JY, DeVries GH, Yachnis AT, Wallace MR, Muir D (2007) Plexiform-like neurofibromas develop in the mouse by intraneural xenograft of an NF1 tumor-derived Schwann cell line. J Neurosci Res 85(6):1347-1357. doi:10.1002/jnr.21226

50. Tzeng S-F, Deibler GE, Neuberger TJ, DeVries GH (1995) Two mitogenic regions of myelin basic protein interact with different receptors to induce Schwann cell proliferation in a cAMP mediated process. J Neurosci Res 42:758-767. doi:10.1002/jnr. 490420604
51. Tzeng S-F, Deibler GE, DeVries GH (1999) Myelin basic protein and myelin basic protein peptides induce the proliferation of Schwann cells via ganglioside GM1 and the FGF receptor. Neurochem Res 24(2):255-260. doi:10.1023/A:1022514105129

52. Tzeng S-F, Deibler GE, DeVries GH (1996) Exogenous myelin basic protein promotes oligodendrocyte death via increased calcium influx. J Neurosci Res 42:768-774. doi:10.1002/jnr.490420605

53. DeVries GH (2004) Cryptic axonal antigens and axonal loss in multiple sclerosis. Neurochem Res 29(11):1999-2006. doi: 10.1007/s11064-004-6873-1

54. Bigbee JW, Calabrese VP, DeVries GH (1985) Characterization of an anti-serum against an axolemma-enriched fraction. J Neuroimmunol 7:221-229. doi:10.1016/S0165-5728(84)80022-3

55. Yoshino JE, Dinneen MP, Lewis BL, Meador-Woodruff JH, DeVries GH (1984) Differential proliferative responses of cultured Schwann cells to axolemma- and myelin-enriched fractions. I. Biochemical studies. J Cell Biol 99:2309-2313. doi:10.1083/ jcb.99.6.2309

56. Meador-Woodruff JH, Yoshino JE, Bigbee JW, Lewis BL, DeVries GH (1985) Differential proliferative responses of cultured Schwann cells to axolemma and myelin-enriched fractions. II. Morphological studies. J Neurocytol 14:619-635. doi: 10.1007/BF01200801

57. Bigbee JW, Yoshino JE, DeVries GH (1987) Morphological and proliferative responses of cultured Schwann cells following rapid phagocytosis of a myelin-enriched fraction. J Neurocytol 16:487496. doi:10.1007/BF01668503

58. Baichwal RR, Bigbee JW, DeVries GH (1988) Macrophagemediated myelin-related mitogenic factor for cultured Schwann cells. Proc Natl Acad Sci USA 85:1701-1705. doi:10.1073/pnas. 85.5.1701

59. Baichwal RR, DeVries GH (1989) A mitogen for Schwann cells is derived from myelin basic protein. Biochem Biophys Res Commun 164:883-888. doi:10.1016/0006-291X(89)91541-6

60. Baichwal RR, DeVries GH (1992) A mitogenic factor derived from the myelin membrane. In: Martenson R (ed) Myelin: biology and chemistry. CRC press, Boca Rotan, pp 633-649

61. Knight RM, Fossom LH, Neuberger TJ, Attema BL, Tennekoon G, Bharucha V, DeVries GH (1993) Increased P0 glycoprotein gene expression in primary and transformed rat Schwann cells after treatment with axolemma-enriched fractions. J Neurosci Res 35:38-45. doi:10.1002/jnr.490350106

62. DeCoster MA, DeVries GH (1989) Evidence that the axolemmal mitogen for cultured Schwann cells is a positively charged, heparan sulfate proteolycan-bound, heparin-displaceable molecule. J Neurosci Res 22:283-288. doi:10.1002/jnr.490220308

63. Raabe TD, Deadwyler G, Varga JW, DeVries GH (2004) Localization of neuregulin isoforms and erbB receptors in myelinating glial cells. Glia 45:197-207. doi:10.1002/glia.10311

64. Francis A, Raabe TD, Wen D, DeVries GH (1999) Neuregulins and erbB receptors in cultured neonatal astrocytes. J Neurosci Res 57:487-494. doi:10.1002/(SICI)1097-4547(19990815)57: 4<487::AID-JNR8>3.0.CO;2-W

65. Raabe TD, Francis A, DeVries GH (1998) Neuregulins in glial cells. Neurochem Res 233:311-318. doi:10.1023/A:10224492 31651

66. Raabe TD, Clive DR, Neuberger TJ, Wen D, DeVries GH (1996) Cultured neonatal Schwann cells contain and secrete neuregulins. J Neurosci Res 46:263-270. doi:10.1002/(SICI)1097-4547(19961015) 46:2<263::AID-JNR15>3.0.CO;2-3

67. Calderon RO, Maggio B, Neuberger TJ, DeVries GH (1993) Surface behavior of axolemma monolayers: Physico-chemical characterization and use as supported planar membranes for cultured glial cells. J Neurosci Res 34:206-218. doi:10.1002/jnr. 490340208 
68. Calderon RO, Maggio B, Neuberger TJ, DeVries GH (1995) Modulation of Schwann cell P0 glycoprotein and galactocerebroside by the surface organization of axolemma. J Neurosci Res 40:349-358. doi:10.1002/jnr.490400309

69. Thudichum JLW (1884) A treatise on the chemical constitution of the brain. Tindall \& Cox, Bailliere

70. Yoshino JE, DeVries GH (1993) Isolation and characterization of axolemma-enriched fractions from rabbit and bovine peripheral nerve. Neurochem Res 18:297-303. doi:10.1007/BF00969086

71. Thomas S, DeVries GH (2009) Neurofibromatosis type I: from genetic mutations to tumor formation. In: Banik N, Swapan K (eds) Handbook of neurochemistry and molecular neurobiology, Editor-in-Chief Abel Lajtha, vol 8, 3rd edn

72. Badache A, Muja N, DeVries GH (1998) Expression of Kit in neurofibromin-deficient Schwann cells: role in Schwann cell hyperplasia associated with Type 1 Neurofibromatosis. Oncogene 17:795-800. doi:10.1038/sj.onc. 1201978

73. Badache A, DeVries GH (1998) Neurofibrosarcoma-derived Schwann cells overexpress PDGF receptors and are induced to proliferate by PDGF BB. J Cell Physiol 177:334-342. doi:10.1002/ (SICI)1097-4652(199811)177:2<334::AID-JCP15>3.0.CO;2-9

74. Deadwyler GD, Dang I, Nelson J, Srikanth M, DeVries GH (2004) Prostaglandin E2 Metabolism is activated in Schwann cell lines derived from human NF1 malignant peripheral nerve sheath tumors. Neuron Glia Biol 1(2):149-155. doi:10.1017/S17409 25X04000262

75. Dang I, DeVries GH (2005) Schwann cell lines derived from malignant peripheral nerve sheath tumors respond abnormally to platelet-derived growth factor BB. J Neurosci Res 79:318-325. doi:10.1002/jnr.20334

76. Dang I, DeVries GH (2005) C-kit receptor expression in normal human Schwann cells and Schwann cell lines derived from NF1 tumors. J Neurosci Res 82:465-471. doi:10.1002/jnr.20648

77. Thomas SL, DeVries GH (2007) Angiogenic expression profile of normal and neurofibromin-deficient human Schwann cells. Neurochem Res 32(7):1129-1141. doi:10.1007/s11064-007-9279-z

78. Rawes JA, Calabrese VP, Khan OA, DeVries GH (1998) Antibodies to the axolemma-enriched fraction in the cerebrospinal fluid and serum of patients with multiple sclerosis and other neurological disease. Mult Scler 3:363-369

79. DeVries GH, Markus TM, Rosales J, Bollnow MR, Farrer RG, Schwab ME, Kartje GL (2004) Effects of Nogo-A blockade after a focal demyelinating lesion. J Neurochem Suppl 90:68

80. Campbell C, Schwartz RF, Feinstein D, Becker-Catania S, Dupree J, Muller HJ, Elford H, DeVries GH (2008) Didox ameliorates and reverses clinical symptoms EAE. J Neurochem 104(Suppl 1):118-119

81. Folch J, Lees M, Sloane-Stanley GH (1957) A simple method for the isolation and purification of total lipids from animal tissue. J Biol Chem 226:497-509

82. DeVries GH, Lazdunski M (1982) The binding of two classes of neurotoxins to axolemma of mammalian brain. J Biol Chem 257:11684-11688 